\title{
AN EMPIRICAL ANALYSIS OF ENERGY DEMAND IN TURKEY: ESTIMATING PRICE AND INCOME ELASTICITIES OF CRUDE OIL WITH DIFFERENT DATA FREQUENCIES
}

\author{
Muhammet Yunus ŞiŞMAN ${ }^{1 *}$ \\ Özcan ÖZTÜRK²
}

\begin{abstract}
The present study aims to examine crude oil import demand in Turkey. The country has quite limited oil production and is dependent on foreign supply to power its growing economy. We estimate the price and income elasticities of imported crude oil for Turkey exploiting three different data sets (i.e., monthly, quarterly, and annual) to test whether data frequency matters in estimation. We employ an Auto Regressive Distributed Lag (ARDL) model which shows both short-run and long-run effects of price and income changes on crude oil import demand. Results show that i) data frequency plays an important role in the estimation process as the findings of monthly and quarterly model show a long-run equilibrium while annual models do not and that ii) the estimated elasticities of monthly and quarterly data are in line with microeconomic theory and literature in that price elasticities are inelastic suggesting that consumers are less responsive to the price changes due to high dependency and lack of substitute for crude oil and that income elasticities are elastic suggesting the demand for crude oil increases as income level increases.
\end{abstract}

Keywords: Turkey, Data Frequency, Crude Oil Demand Elasticities, ARDL Bounds Test Approach JEL classification: F10, F14, Q41

\section{TÜRKIYYE'DE ENERJİ TALEBİ ÜZERINE AMPIRIKK BİR ANALIZ: HAM PETROL ITHALAT TALEBİNIN GELIR VE FIYYAT ESNEKLIKLERININ FARKLI VERI FREKANSLARI İÇIN TAHMIN EDILMESI}

\begin{abstract}
$\ddot{\mathbf{O} z}$
Bu çalışma, Türkiye'deki ham petrol ithalat talebini incelemeyi amaçlamaktadır. Ülke, çok sınırlı petrol üretimine sahip olmakla beraber büyüyen ekonomisini ithal edilen petrol arzına bağımlı olarak desteklemektedir. Çalışmamızda, Türkiye'nin ithal ham petrol talebi fiyat ve gelir esnekliklerini farklı veri frekansları için (aylık, çeyreklik, yıllık) hesaplarken veri sıklığının tahminler üzerindeki etkisini inceledik. Araştırmamızda, fiyat ve gelir değişikliklerinin ham petrol ithalat talebi üzerindeki kısa ve uzun vadeli etkilerini gösteren Oto Regresif Gecikmeli Dağıtılmış (ARDL) modelini kullandık. Elde edilen sonuçlar; i) veri sıklığının sıklığının tahmin sürecinde önemli bir rol oynadığını, aylık ve çeyreklik veri modelleri bulgularının uzun dönemde denge durumunda olmasına karşın yıllık veri modelinde dengenin bulunamadığı ii) aylık ve çeyreklik verilerin tahmin edilen fiyat ve gelir esneklikleri mikroekonomik teori ve literatürle uyumludur. Esnek olmayan fiyat esneklikleri tüketicilerin yüksek bağımlılık ve ham petrolün ikamesinin olmaması nedeniyle fiyat değişikliklerine daha az tepki verdiğini gösterirken gelir esnekliklerinin esnek olması, gelir düzeyi arttıkça ham petrol talebinin arttığını göstermektedir.

Anahtar kelimeler: Türkiye, Veri Frekansı, Ham Petrol İthalat Esneklikleri, ARDL Sınır Testi Yaklaşımı Jel Kodları: F10, F14, Q41

\footnotetext{
1* Dr. Öğr. Üyesi, Kütahya Dumlupınar Üniversitesi, İIBF, İktisat, ORCID 0000-0002-9791-1382

Sorumlu yazar (Corresponding Author): myunus.sisman@dpu.edu.tr

${ }^{2}$ Dr. Öğr. Üyesi Hamad Bin Khalifa Üniversitesi0000-0002-2187-4327

Başvuru Tarihi (Received): 21.05.2021 Kabul Tarihi (Accepted): 29.07.2021
} 
Türkiye'de Enerji Talebi Üzerine Ampirik Bir Analiz: Ham Petrol İthalat Talebinin Gelir ve Fiyat Esnekliklerinin Farklı Veri Frekansları İçin Tahmin Edilmesi

\section{Introduction}

Energy resources are considered as one of the main drivers of economic growth and they have been at the center of economic literature. Several aspects of energy are still being extensively studied. Particularly, the relationship between energy and environment is currently scrutinized by a large body of the literature due to the unprecedented global environmental degradation. Promoting renewable energy resources is a widely accepted environmental policy in this regard. Yet, fossil based energy commodities (e.g., crude oil) are the major energy supply for the world economy.

Turkey is among the top 20 economies in the world and one of the fasting growing economies in OECD countries during the last decade. The country is also one of the most populous nations in Europe. Historically, Turkey is powering its economy by fossil fuels mainly imported from the world markets, except domestically produced coal. Its strategic location bordered with the major energy producing countries has not effectively provided solutions to Turkey's dependency on energy imports. In fact, being a highly dependent country on foreign energy supply (i.e., crude oil) poses political and economic threats to Turkey as the energy imports are one of the main drivers of long lasting macroeconomic issues such as higher inflation, current deficit, and exchange rate volatility. Despite the country's significant investments on renewables, crude oil imports have a key importance for Turkish economy due to its negligible domestic production.

This study employs a single-equation import demand function and aims to estimate Turkey's crude oil import demand elasticities during the period between 1996 and 2021. The paper uses Auto Regressive Distributed Lag (ARDL) to estimate the effects of price and income changes on imported crude oil demand and provide price and income elasticities for the short-run and the longrun. We test whether data frequency matters in estimation process using three different data sets that differ in frequency (i.e., monthly, quarterly, and yearly). Demand elasticities are among the key inputs for policy makers allowing them to explore the dynamics of the markets. Therefore, the outcome of this research is expected to provide useful insights for the energy policies.

The elasticity estimates are consistent with the demand theory. Namely, we have negative and statistically significant price elasticities and positive and statistically significant income elasticities for imported demand in our models for monthly and quarterly data. These models suggest similar results. Findings suggest that crude oil demand elasticities are inelastic with respect to the prices, implying that the Turkish demand is less responsive to the price changes. Highly inelastic import demand also indicates that substituting crude oil with other energy sources is very limited. We find that elasticity estimates for annual data model show significant disparities from the high frequency data.

The paper is outlined as follows. The next section presents the existing literature on economics of crude oil in the Turkish energy market. Section 3 provides the data description and empirical framework used in the analysis. Then, ARDL results and income and price elasticity estimates for crude oil import demand are presented. The last section concludes with the key remarks and policy suggestions.

\section{Literature Review}

A substantial body of research examine crude oil markets in Turkey. Existing literature mainly examines the impact of crude oil price on macroeconomic indicators and financial markets. Among others, one strand of this literature explore the relationship between exchange rates and crude oil prices (e.g., Bilgic et al. 2019; Gülay and Pazarlığlu 2016; Adıgüzel et al. 2013; Ozturk et al. 2008). In addition, the inflationary effects of crude oil and pass-through of crude oil prices to the domestic commodity prices are also analyzed in the recent literature (e.g., Akcelik and Ogunc, 2016; Gokmenoglu et al. 2015; Çatık and Karaçuka, 2012; Berument and Taşç1, 2002). Sari and 
Soytas (2006) Soytas et al. (2009), and Dogrul and Soytas (2010) explore the nexus between crude oil prices and interest rates in Turkey. The second strand of the literature reviews the link between crude oil prices and financial markets (Polat 2020; Akkoc and Civcir 2019; Bildirici and Badur 2019; Toparli et al. 2019; Tursoy and Faisal, 2018; Kayalar et al. 2017; Anoruo 2011).

Contrary to the large body of current literature on macroeconomics of crude oil, a limited research provides crude oil import demand elasticities for Turkey. Altinay (2007) presents an analysis on crude oil import demand in Turkey. The study reports the income elasticity of imported crude oil as 0,64 and price elasticities of imported crude oil as -0,10. The corresponding long run elasticities are also inelastic $(0,61$ and $-0,18$, respectively) for the period between 1980 and 2005. Solak and Beşkaya (2013) reports short and long run income elasticities of imported crude oil as $(1,11)$ and $(0,67)$, respectively, while showing that price elasticities are insignificant. Yaprakli and Kaplan (2015) investigates the imported crude oil demand elasticities by employing dynamic ordinary least squares estimation and reported the long run income and price elasticities of imported crude oil demand as (0.18) and (-0.25), respectively. Ozturk and Arisoy (2016) estimates the price and expenditure elasticities for crude oil imports using a time-varying parameters (TVP) approach. In contrast to previous studies, their findings suggest that the income elasticity of import demand for crude oil is elastic (1.18) with a statistically insignificant the price elasticity of imported crude oil. In a more recent study, Kavaz (2020) estimates the income and price elasticities by using Harvey's Structural Time Series Modelling Method $(0,66)$ and $(-0,11)$, respectively. The only study estimating imported crude oil demand elasticities with a different frequency data (i.e., monthly) is Gorus et al. (2019) who finds statistically significant short-run $(0,35)$ and long-run $(1,04)$ income elasticities.

This study aims to analyze the import demand for crude oil and estimate the expenditure and price elasticities for Turkey. In particular, the present paper estimate the import demand elasticities for high and low frequency data to test whether the data frequency matters for estimated elasticities. Therefore, our study contributes the current literature by providing most recent elasticity estimates as well as potential explanation for inconclusive findings in the literature.

\section{Data and Empirical Framework: The Estimation of Import Demand Function}

The empirical analysis covers the data for the period of 1996-2021. The single-equation model requires price, quantity, and income data for the estimation. We obtain monthly data for imported crude oil quantity from the Turkish Statistical Institute. The Central Bank of Turkey provides the Brent petrol price data reported as Europe Brent Spot Price F.O.B (US Dollars/Barrel). Annual and quarterly GDP data are obtained from the Federal Reserve of St-Louis (FRED). Since monthly GDP is not available, we approximate production of total industry index obtained from FRED.

In economic theory and in the empirical literature, the import demand is expressed as a function of income and relative prices:

$M=f(Y, P)$

where $\mathrm{M}$ is the quantity of crude oil imports, $\mathrm{Y}$ represents the real Gross Domestic Product (GDP), and $\mathrm{P}$ represents the price of crude oil. Conventionally, this relationship is specified as a singleequation expressed in linear logarithmic form linking the quantity of energy product imported with real income and price.

$$
\ln M_{t}=\beta_{0}+\beta_{1} \ln Y_{t}+\beta_{2} \ln P_{t}+\varepsilon_{t}
$$

Where $\ln$ is the logarithmic form of the variables, the subscript $t$ represents time, $\beta_{0}$ is intercept term, $\beta_{1}$ and $\beta_{2}$ are estimators of the expenditure and price elasticities of import demand respectively, and $\varepsilon$ denotes for the error term which is assumed to be white noise with zero means, 
non-correlated and constant variance. Since the variables are in natural log form, the coefficients $\beta_{1}$ and $\beta_{2}$ can be interpreted as income and price elasticities. The expected sign is positive for income elasticity $\left(\beta_{1}>0\right)$ and negative $\left(\beta_{2}<0\right)$ for price elasticity.

Various methods can be used to estimate time series data such as Vector Autoregressive (VAR) and Error Correction Model (ECM). However, Autoregressive Distributed Lag (ARDL) has several advantages compared to others. ARDL method does not require variables to be integrated of the same order. It can be used whether the variables are I(0) and/or I(1). Moreover, ARDL performs better if the sample size is small. Third, ARDL estimates both the short-term and the long-term effects conveniently. Finally, Paseran et al.(2001) indicates that there is no need for a unit-root test because the critical values of the $\mathrm{F}$ test that they tabulate has integrating properties of all variables in a given model. Hence this study employs ARDL model.

ARDL model is estimated in two steps. The first step is to examine whether a long-run relationship exists between the variables. In other words, the first step test whether the variables are cointegrated. Once co-integration is confirmed, the next stage is to estimate the short-run and the long-run variables using ARDL or ECM. To test for co-integration in model (2), the following ARDL model is constructed.

$$
\begin{aligned}
& \Delta \ln M_{t}=\delta_{0}+\sum_{j=1}^{n} \delta_{1} \Delta \ln M_{t-j}+\sum_{j=0}^{n} \delta_{2} \Delta \ln Y_{t-j}+\sum_{j=0}^{n} \delta_{3} \Delta \ln P_{t-1}+\theta_{1} \ln M_{t-1}+ \\
& \theta_{2} \ln Y_{t-1}+\theta_{3} \ln P_{t-1}+\varepsilon_{t}
\end{aligned}
$$

In equation (3) the first-differenced variables $\left(\delta_{1}-\delta_{3}\right)$ indicates the short-run effects while variables represented in level $\left(\theta_{1}-\theta_{3}\right)$ reflect the long-run effects. Estimation of equation (3) gives both the short-run and the long-run effects at once. For the long-run variables to be meaningful, co-integration should exist among the variables. Paseran et al. propose employing the F-test for joint significance of the lagged level variables.

\section{Results and Discussion}

Tables 1a to 1c show the results of F-tests for co-integration. The F-statistics in the case of monthly and quarterly data are greater than upper and lower bounds of the tabulated critical values, which confirms the presence of co-integration in the two models. The F-statistic does not confirm the existence of co-integration for annual model. Hence, we will not report the coefficient estimation for annual data.

Since a long-run relationship exists between the variables for monthly and quarterly models, the coefficients for short-run and long run in equation (3) can be estimated for them.

The unit root test results presented in table 2 show a mix results of stationarity at level I(0) and first-difference I(1). All variables at level are non-stationary with the exception of import variable while all variables are stationary at first difference. The different level of integration between the variables suggests that ARDL model is an appropriate approach to estimate coefficients.

The estimated coefficients are presented for both short and long terms in table 3. In monthly model, the coefficients of price elasticity are statistically significant in both the short-run and long- run with the expected sings. It has a -0.06 of magnitude in the short-run suggesting that every 10 percent increase in oil prices would cause a 0.6 percent decrease in oil import demand, which is negligibly small showing the inelastic nature of Turkey's import demand. The price elasticity in the long-run is -0.2 which suggests that every 10 percent increase in oil price would cause a 2 percent decrease in the long-run. The short-run expenditure elasticity is not statistically significant while it is in the long-run with 0.25 magnitude showing that as income rises by 10 percent, import demand rises by its quarter. 
In quarterly model, the price elasticity in the short-run is not statistically significant, while it is in the long run with -0.38 estimated coefficient suggesting that every 10 percent increase would lead to 3.8 percent decrease in import demand for crude oil.

Table 1a: $F$ test for monthly model

\begin{tabular}{|c|c|c|c|c|}
\hline \multirow{2}{*}{$\begin{array}{l}\text { F-Bounds Test } \\
\text { Test Statistic }\end{array}$} & \multicolumn{4}{|c|}{ Null Hypothesis: No levels relationship } \\
\hline & Value & Signif. & $\mathbf{I}(\mathbf{0})$ & I(1) \\
\hline & & & Asymptotic: $n=1000$ & \\
\hline F-statistic & 7.824177 & $10 \%$ & 2.63 & 3.35 \\
\hline \multirow[t]{3}{*}{$\mathbf{k}$} & 2 & $5 \%$ & 3.1 & 3.87 \\
\hline & & $2.50 \%$ & 3.55 & 4.38 \\
\hline & & $1 \%$ & 4.13 & 5 \\
\hline \multirow[t]{5}{*}{ Actual Sample Size } & 299 & & Finite Sample: $\mathrm{n}=$ & \\
\hline & & $10 \%$ & 2.713 & 3.453 \\
\hline & & $5 \%$ & 3.235 & 4.053 \\
\hline & & $1 \%$ & 4.358 & 5.393 \\
\hline & & $1 \%$ & 4.358 & 5.393 \\
\hline
\end{tabular}

Table 1b: F test for quarterly model

\begin{tabular}{llllc}
\hline F-Bounds Test & & \multicolumn{3}{l}{ Null Hypothesis: No levels relationship } \\
\hline Test Statistic & Value & Signif. & \multicolumn{1}{l}{ I(0) } & I(1) \\
\hline \multirow{3}{*}{ F-statistic } & & & Asymptotic: $\mathrm{n}=1000$ \\
$\mathbf{k}$ & 9.723946 & $10 \%$ & 2.63 & 3.35 \\
& 2 & $5 \%$ & 3.1 & 3.87 \\
& & $2.50 \%$ & 3.55 & 4.38 \\
Actual Sample Size & \multirow{2}{*}{96} & $1 \%$ & 4.13 & 5 \\
& & & Finite Sample: & $\mathrm{n}=80$ \\
& & $10 \%$ & 2.713 & 3.453 \\
& & $5 \%$ & 3.235 & 4.053 \\
& & $1 \%$ & 4.358 & 5.393 \\
\hline
\end{tabular}

Table 1c: $F$ test for annual model

\begin{tabular}{|c|c|c|c|c|}
\hline F-Bounds Test & \multicolumn{4}{|c|}{ Null Hypothesis: No levels relationship } \\
\hline Test Statistic & Value & Signif. & $\mathbf{I}(\mathbf{0})$ & I(1) \\
\hline & & & \multicolumn{2}{|c|}{ Asymptotic: $n=1000$} \\
\hline F-statistic & 1.824177 & $10 \%$ & 3.17 & 4.14 \\
\hline \multirow[t]{3}{*}{$\mathbf{k}$} & \multirow[t]{3}{*}{2} & $5 \%$ & 3.79 & 4.85 \\
\hline & & $2.50 \%$ & 4.41 & 5.52 \\
\hline & & $1 \%$ & 5.15 & 6.36 \\
\hline \multirow[t]{4}{*}{ Actual Sample Size } & \multirow[t]{4}{*}{24} & & \multicolumn{2}{|c|}{ Finite Sample: $n=80$} \\
\hline & & $10 \%$ & 3.393 & 4.41 \\
\hline & & $5 \%$ & 4.183 & 5.333 \\
\hline & & $1 \%$ & 6.14 & 7.607 \\
\hline
\end{tabular}

Although price elasticity in quarterly model is greater than in monthly model in size, they both are statistically significant and inelastic in the long-run.

Income elasticities are statistically significant both in the short and long terms with 0.8 and 1.4 coefficients respectively suggesting that a 10 percent increase in income would increase oil import demand by 8 percent in the short run and 14 percent in the long run. The income elasticities are lager in magnitude both in short and long terms compared to monthly model. 
Türkiye'de Enerji Talebi Üzerine Ampirik Bir Analiz: Ham Petrol İthalat Talebinin Gelir ve Fiyat Esnekliklerinin Farklı Veri Frekansları İçin Tahmin Edilmesi

To assess the validity of the model, we tested the model assumptions for serial correlation, normality, and constant variance (outputs are in appendix).

Table 2: Unit Root Test Results

\begin{tabular}{|c|c|c|c|}
\hline \multicolumn{4}{|c|}{ ADF tests } \\
\hline Time & Variable & Constant & Constant\&trend \\
\hline \multirow{6}{*}{ Monthly } & $\mathrm{M}$ & $-4.91 * * *$ & $-4.97 * * *$ \\
\hline & $\mathrm{P}$ & -2.32 & -2.59 \\
\hline & $\mathrm{Y}$ & -0.12 & -3.89 \\
\hline & $\Delta \mathrm{M}$ & $-33.33 * * *$ & $-33.27 * * *$ \\
\hline & $\Delta \mathrm{P}$ & $-13.53 * * *$ & $-13.51 * * *$ \\
\hline & $\Delta \mathrm{Y}$ & $-14.74 * * *$ & $-12.88 * * *$ \\
\hline \multirow{6}{*}{ Quarterly } & $\mathrm{M}$ & $-4.58 * * *$ & $-4.60 * * *$ \\
\hline & $\mathrm{P}$ & -2.33 & -2.56 \\
\hline & $\mathrm{Y}$ & -0.59 & $-4.77 * * *$ \\
\hline & $\Delta \mathrm{M}$ & $-10.45 * * *$ & $-10.40 * * *$ \\
\hline & $\Delta \mathrm{P}$ & $-10.53 * * *$ & $-10.49 * * *$ \\
\hline & $\Delta \mathrm{Y}$ & $-9.72 * * *$ & $-9.63 * * *$ \\
\hline \multirow{6}{*}{ Annually } & $\mathrm{M}$ & $-4.35 * * *$ & $-4.45 * * *$ \\
\hline & $\mathrm{P}$ & -2.06 & -2.32 \\
\hline & $\mathrm{Y}$ & -1.47 & -0.18 \\
\hline & $\Delta \mathrm{M}$ & $-4.48 * * *$ & $-4.09 * * *$ \\
\hline & $\Delta \mathrm{P}$ & $-6.29 * * *$ & $-6.22 * * *$ \\
\hline & $\Delta \mathrm{Y}$ & $-3.99 * * *$ & $-4.39 * * *$ \\
\hline
\end{tabular}

*** Represents 1\% significance level, $\Delta$ represents the first difference of the variables.

Breusch-Godfrey Serial Correlation LM test is utilized to detect for any autocorrelation issue. The null hypothesis is that there is no serial correlation in the data used. The outputs shown in Appendix Tables 4a-4c have corresponding p-values that are greater than 0.05 . Therefore, we fail to reject the null hypothesis implying that we accept the null hypothesis and the models are not serially correlated.

Table 3: Short-run and Long-run Estimation Results

\begin{tabular}{llrrrr}
\hline Time & Variables & Coefficient & SE & t-Statistic & Prob \\
\hline & intercept & 4.187 & 0.757 & 5.528 & 0.000 \\
& $\Delta \mathrm{P}$ & $-0.061^{* *}$ & 0.023 & -0.596 & 0.010 \\
Monthly Model & $\Delta \mathrm{Y}$ & 0.316 & 0.267 & 1.181 & 0.201 \\
& $\mathrm{P}$ & $-0.207 * * *$ & 0.067 & -3.072 & 0.002 \\
& $\mathrm{Y}$ & $0.257^{* *}$ & 0.114 & 2.252 & 0.025 \\
\hline & intercept & 3.568 & 1.477 & 2.415 & 0.018 \\
& $\Delta \mathrm{P}$ & -0.002 & 0.057 & -0.034 & 0.974 \\
Quarterly Model & $\Delta \mathrm{Y}$ & $0.798^{* * *}$ & 0.222 & 3.611 & 0.000 \\
& $\mathrm{P}$ & $-0.375^{* * *}$ & 0.069 & -5.694 & 0.000 \\
& $\mathrm{Y}$ & $1.390^{* * *}$ & 0.386 & 3.600 & 0.005 \\
\hline
\end{tabular}

$\Delta$ represents short-run variables. ** represents $5 \%$ significance level while *** represents $1 \%$ significance level.

To check the model validity for a constant variance in the error terms, we employed Breusch Pagan Godfrey test to check the heteroskedasticity in data. The null hypothesis is that there is no heteroskedasticity, which means the variance is not constant in the data. According to the results shown in Tables 5a-5c, the corresponding p-values are greater than 0.05 , which suggest the rejection of the null hypothesis. Thus, the results show that there is a constant variance in the data. To test if the data are normally distributed, we use Jarque-Bera test which has the null hypothesis stating that the data are normally distributed. The first two models suffer from non-normality while 
the last one is normally distributed. The estimated long run income elasticity $(0.25)$ and price elasticity (-0.20) in monthly model are inelastic and have theoretically expected sings. They are closely in line with the findings of Altinay (2007), Yaprakli and Kaplan (2015), and Kavaz (2020). Similarly, the estimated income elasticity (1.39) and price elasticity in the quarterly model has the expected sing and is elastic which is consistent with the findings of Ozturk and Arisoy (2016) and Gorus et al. (2019). The price elasticity (-0.37) in the quarterly model is inelastic with the expected sign and in consistent with the findings of Altinay (2017), Yaprakli and Kaplan (2015), and Kavaz (2020).

\section{Conclusion and Policy Implications}

This paper attempts to (1) estimate price and income elasticities for imported crude oil demand utilizing an up-to-date data set, and (2) test whether data frequency matters in estimation process using three different data frequency; monthly, quarterly and yearly. Employing an ARDL bounds test approach, we run three models with three data sets covering the period of 1996-2021 to estimate both short and long term price and expenditure elasticities.

Our elasticity estimates are consistent with theory. The estimated price elasticities of imported crude oil demand have negative signs and the expenditures elasticities are positive. Findings suggest that crude oil demand elasticities are highly inelastic with respect to the import prices, indicating that the Turkish demand is not responsive to the import price changes due to its dependency on outside sources. Inelastic import demand also implies limited substitute of crude oil with other energy sources for the Turkish economy.

Findings also reveal that data frequency indeed matters in estimation process as it can cause significant disparities in results. Accordingly, the model with annul data does not indicate a cointegration between the variables, while monthly and quarterly models do. Moreover, the estimations with monthly and quarterly models generate similar results and are consistent with microeconomic theory, which has a significant implication for further research. For future studies, we recommend re-estimating price and income elasticities using high frequency data(montly, quarterly) as current estimations rely mostly on yearly data.

Yazarlık Katkıları (Authorship Contributions): Muhammet Yunus Şişman, Özcan Öztürk

\section{References}

Adıgüzel, U., Bayat, T., Kayhan, S., \& Nazlığlu, Ş. (2013). Oil prices and exchange rates in Brazil, India \& Turkey: Time and frequency domain causality analysis. Siyaset, Ekonomi ve Yönetim Araştırmaları Dergisi, 1(1), 49-73.

Akcelik, F., \& Ögünç, F. (2016). Pass-through of crude oil prices at different stages in Turkey. Central Bank Review, 16(1), 41-51.

Akkoc, U., \& Civcir, I. (2019). Dynamic linkages between strategic commodities and stock market in Turkey: Evidence from SVAR-DCC-GARCH model. Resources Policy, 62, 231-239.

Altinay, G. (2007). Short-run and long-run elasticities of import demand for crude oil in Turkey. Energy Policy, 35(11), 5829-5835.

Anoruo, E. (2011). Testing for linear and nonlinear causality between crude oil price changes and stock market returns. International Journal of Economic Sciences \& Applied Research, 4(3), 75-92.

Berument, H., \& Taşçı, H. (2002). Inflationary effect of crude oil prices in Turkey. Physica A: Statistical Mechanics and its Applications, 316(1-4), 568-580. 
Bildirici, M. E., \& Badur, M. M. (2019). The effects of oil and gasoline prices on confidence and stock return of the energy companies for Turkey and the US. Energy, 173, 1234-1241.

Bilgic, A., Yavuz, F., Damba, O. T., \& Bilgin, O. C. (2019). Volatility transmission between prices of selected agricultural products with crude oil and exchanges rates in Ghana and Turkey. Ghanaian Journal of Economics, 7(1), 118-155.

Çatik, A. N., \& Karaçuka, M. (2012). Oil pass-through to domestic prices in Turkey: does the change in inflation regime matter? Economic research-Ekonomska istraživanja, 25(2), 277-296.

Doğrul, H. G., \& Soytas, U. (2010). Relationship between oil prices, interest rate, and unemployment: Evidence from an emerging market. Energy Economics, 32(6), 15231528 .

Gokmenoglu, K., Azin, V., \& Taspinar, N. (2015). The relationship between industrial production, GDP, inflation and oil price: the case of Turkey. Procedia Economics \& Finance, 25, 497 503.

Gorus, M. S., Ozgur, O., \& Develi, A. (2019). The relationship between oil prices, oil imports and income level in Turkey: evidence from Fourier approximation. OPEC Energy Review, 43(3), 327-341.

Gülay, E., \& Pazarlığlu, M. V. (2016). The empirical role of real crude oil price and real exchange rate on economic growth: the case of turkey. Ege Akademik Bakıs Dergisi, 16(4), 627-639.

Kavaz, İ. (2020). Estimating the Price and Income Elasticities of Crude Oil Import Demand for Turkey. International Econometric Review, 12(2), 98-111.

Kayalar, D. E., Küçüközmen, C. C., \& Selcuk-Kestel, A. S. (2017). The impact of crude oil prices on financial market indicators: copula approach. Energy Economics, 61, 162-173.

Ozturk, I., Feridun, M., \& Kalyoncu, H. (2008). Do oil prices affect the USD/YTL exchange rate: Evidence from Turkey.

Ozturk, I., \& Arisoy, I. (2016). An estimation of crude oil import demand in Turkey: Evidence from time-varying parameters approach. Energy Policy, 99, 174-179.

Polat, O. (2020). Time-varying propagations between oil market shocks and a stock market: Evidence from Turkey. Borsa Istanbul Review, 20(3), 236-243

Sari, R., \& Soytas, U. (2006). The relationship between stock returns, crude oil prices, interest rates, and output: evidence from a developing economy. The Empirical Economics Letters, 5(4), 205-220.

Solak, A. O., \& Beşkaya, A. (2013). Türkiye'nin Net Petrol Ithalatinin Fiyat Ve Gelir Esneklikleri: ARDL Modelleme Yaklaşimi ile Eşbütünleşme Analizi. Uluslararası Yönetim İktisat ve İsletme Dergisi, 9(18), 19-29.

Soytas, U., Sari, R., Hammoudeh, S., \& Hacihasanoglu, E. (2009). World oil prices, precious metal prices and macroeconomy in Turkey. Energy Policy, 37(12), 5557-5566.

Toparlı, E. A., Çatık, A. N., \& Balcılar, M. (2019). The impact of oil prices on the stock returns in Turkey: A TVP-VAR approach. Physica A: Statistical Mechanics \& Its Applications, 535, 122392.

Tursoy, T., \& Faisal, F. (2018). The impact of gold and crude oil prices on stock market in Turkey: Empirical evidences from ARDL bounds test and combined cointegration. Resources Policy, 55, 49-54. 
Yaprakli, S., \& Kaplan, F. (2015). Re-examining of the Turkish crude oil import demand with multi-structural breaks analysis in the long run period. International Journal of Energy Economics \& Policy, 5(2), 402-407.

\section{Appendix}

Table 4a: Breusch-Godfrey Serial Correlation LM Test for monthly data

\begin{tabular}{llll}
\hline \hline F-statistic & 0.426398 & Prob. F(2,289) & 0.6533 \\
Obs*R-squared & 0.879708 & Prob. Chi-Square(2) & 0.6441 \\
\hline
\end{tabular}

Table 4b: Breusch-Godfrey Serial Correlation LM Test for quarterly data

\begin{tabular}{llll}
\hline \hline F-statistic & 0.202539 & Prob. F(2,88) & 0.8170 \\
Obs*R-squared & 0.439878 & Prob. Chi-Square(2) & 0.8026 \\
\hline \hline
\end{tabular}

Table 4c: Breusch-Godfrey Serial Correlation LM Test for annual data

\begin{tabular}{llll}
\hline \hline F-statistic & 0.693618 & Prob. F(2,16) & 0.5142 \\
Obs*R-squared & 1.914835 & Prob. Chi-Square(2) & 0.3839 \\
\hline
\end{tabular}

Table 5a: Heteroskedasticity Test: Breusch-Pagan-Godfrey for monthly data

\begin{tabular}{llll}
\hline \hline F-statistic & 1.217732 & Prob. F(7,291) & 0.2927 \\
Obs*R-squared & 8.509208 & Prob. Chi-Square(7) & 0.2898 \\
Scaled explained SS & 14.50508 & Prob. Chi-Square(7) & 0.0429 \\
\hline \hline
\end{tabular}

Table 5b: Heteroskedasticity Test: Breusch-Pagan-Godfrey for quarterly data

\begin{tabular}{llll}
\hline \hline & & & \\
F-statistic & 2.458170 & Prob. F(5,90) & 0.0390 \\
Obs*R-squared & 11.53497 & Prob. Chi-Square(5) & 0.0417 \\
Scaled explained SS & 15.47153 & Prob. Chi-Square(5) & 0.0085 \\
\hline \hline
\end{tabular}

Table 5c: Heteroskedasticity Test: Breusch-Pagan-Godfrey for annual data

\begin{tabular}{llll}
\hline \hline F-statistic & 1.117981 & Prob. F(5,18) & 0.3859 \\
Obs*R-squared & 5.687081 & Prob. Chi-Square(5) & 0.3379 \\
Scaled explained SS & 2.968969 & Prob. Chi-Square(5) & 0.7048 \\
\hline \hline
\end{tabular}


Türkiye'de Enerji Talebi Üzerine Ampirik Bir Analiz: Ham Petrol İthalat Talebinin Gelir ve Fiyat Esnekliklerinin Farklı Veri Frekansları İçin Tahmin Edilmesi

Figure 1a: Normality test for monthly data

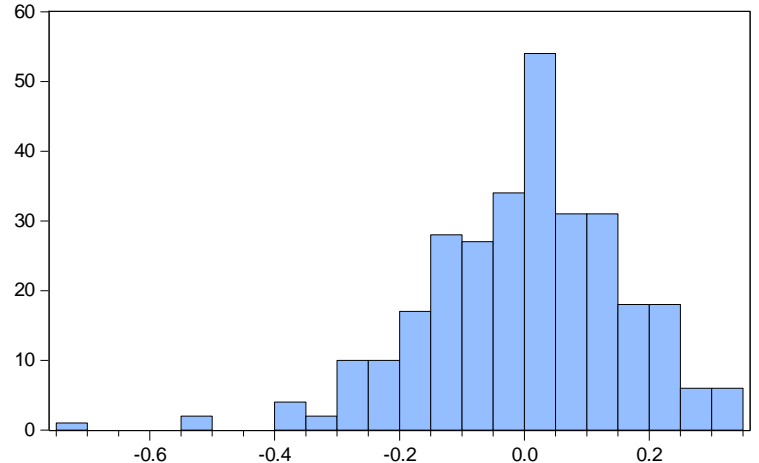

\begin{tabular}{lc}
\multicolumn{2}{l}{ Series: Residuals } \\
Sample 1996M04 2021M02 \\
Observations 299 \\
Mean & $2.43 \mathrm{e}-15$ \\
Median & 0.013378 \\
Maximum & 0.338698 \\
Minimum & -0.746167 \\
Std. Dev. & 0.158227 \\
Skewness & -0.678231 \\
Kurtosis & 4.599294 \\
& \\
Jarque-Bera & 54.78837 \\
Probability & 0.000000
\end{tabular}

Figure 1b: Normality test for quarterly data

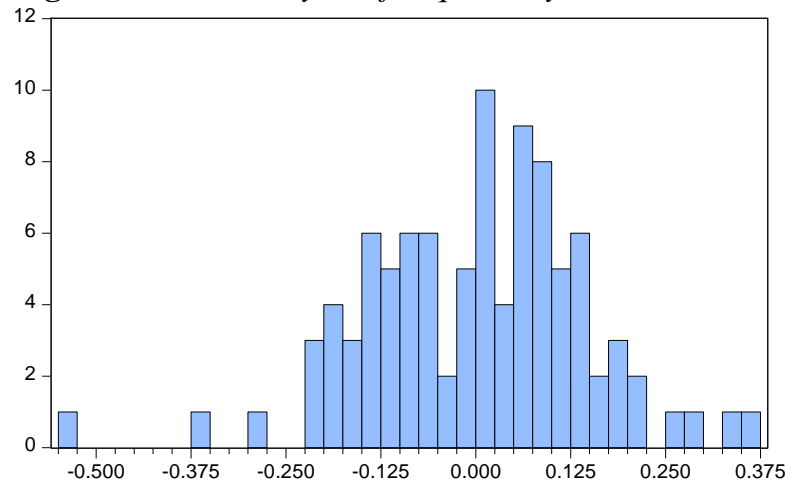

\begin{tabular}{|lr|}
\hline \multicolumn{2}{|l|}{ Series: Residuals } \\
Sample 1997Q1 2020Q4 \\
Observations 96 \\
Mean & $-5.59 \mathrm{e}-16$ \\
Median & 0.009014 \\
Maximum & 0.362540 \\
Minimum & -0.526481 \\
Std. Dev. & 0.145598 \\
Skewness & -0.359716 \\
Kurtosis & 4.052139 \\
& \\
Jarque-Bera & 6.498316 \\
Probability & 0.038807 \\
\hline
\end{tabular}

Figure 1c: Normality test for annual data

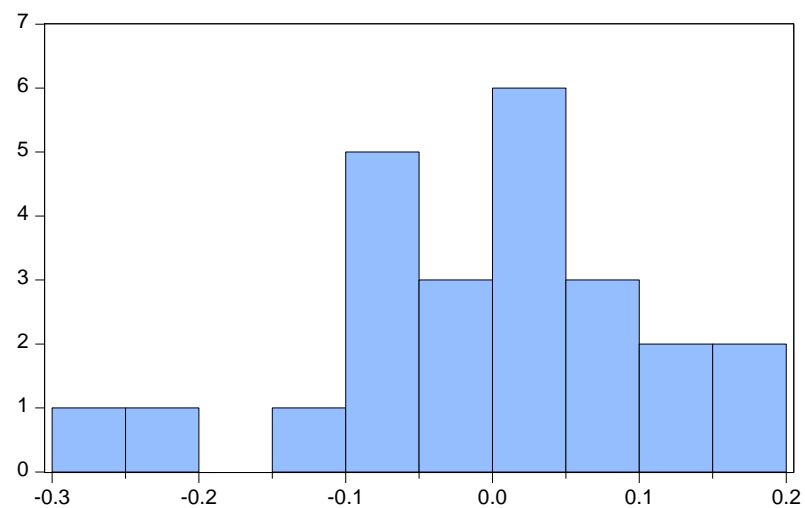

$\begin{array}{lc}\text { Series: Residuals } \\ \text { Sample 1997 } 2020 \\ \text { Observations } 24 \\ \text { Mean } & 2.04 \mathrm{e}-15 \\ \text { Median } & 0.004525 \\ \text { Maximum } & 0.193722 \\ \text { Minimum } & -0.259261 \\ \text { Std. Dev. } & 0.113064 \\ \text { Skewness } & -0.344353 \\ \text { Kurtosis } & 2.856195 \\ & \\ \text { Jarque-Bera } & 0.494996 \\ \text { Probability } & 0.780752\end{array}$

